\title{
Analisi farmakozinetiko/farmakodinamikoa antimikrobianoen erabilera hobetzeko gaixo larrietan
}

\author{
(Pharmacokinetic/pharmacodynamic modeling to optimize \\ antimicrobial agents' dosage in critically ill patients)
}

\author{
Amaia Soraluce Olañeta, Alicia Rodriguez Gascón, Arantxazu Isla Ruiz* \\ PharmaNanoGene, Farmakozinetika, Nanoteknologia eta Terapia Genikoa taldea. \\ Farmazia Fakultatea, Lascaray-Ikergunea. Euskal Herriko Unibertsitatea (UPV/EHU) \\ *arantxa.isla@ehu.eus
}

DOI: $10.1387 /$ ekaia.17849

Onartua: 2017-09-07

Laburpena: Azken urteotan infekzioen tratamendua mundu mailako osasun publikoko arazo bilakatu da, erresistentzien garapenaren ondorioz, bakterio multirresistenteen agerpena izugarri igo baita. Antibiotiko berrien gabeziak merkatuan daudenen dosifikazioen optimizazioaren premia areagotzen du. Zenbait pazientetan, gaixo larrietan esaterako, aipatutakoa egitea bereziki zaila suerta daiteke. Izan ere, beraien egoera fisiopatologikoa dela eta, medikamentuen farmakozinetika eta farmakodinamia eraldatuta daukate. Analisi farmakozinetiko/farmakodinamikoak, Monte Carlo simulazioekin batera, dosifikazio-erregimenen optimizazioa ahalbidetzen du. Horrela, tratamenduaren arrakasta bermatu eta erresistentzien agerpena ekiditen da.

Hitz gakoak: Antibiotikoak, populazio-farmakozinetika, analisi farmakozinetiko/farmakodinamikoa, Monte Carlo simulazioa.

\begin{abstract}
Nowadays, the treatment of infectious diseases has become a global health issue, due to multi-resistant antibiotic bacteria. The lack of new antibiotics enhances urgent need for current antimicrobials' dosing regimens optimization. This could become an extremely challenging duty when treating some kind of patients, such as the critically ill; as due to their physiophatological situation, both pharmacokinetics and pharmacodynamics might be altered. PK/PD analysis, together with Monte Carlo Simulation, might be a useful tool in order to optimize dosing regimens of antibiotic agents and, therefore, improve clinical outcome and diminish emergence of resistances.
\end{abstract}

Keywords: Antibiotic, population pharmacokinetics, PK/PD analysis, Monte Carlo simulation. 


\section{SARRERA}

Gaur egun, infekzioen diagnostikoa eta tratamendua geroz eta konplexuagoa bilakatzen ari da. Populazioaren zahartzeak eta immunokonprometituta dauden pazienteen gorakadak (kirurgia jasandakoak edota kimioterapia hartzen ari direnak, kasu) infekzio bat pairatzeko arriskua duten pertsonen kopurua areagotzen dute. Gainera, nahiz eta antimikrobianoek gaitz horien tratamenduan berebiziko garrantzia eduki duten, ez dira beti behar bezain eraginkorrak izaten; mikroorganismoek denboran zehar medikamentu horiekiko erresistentziak garatu baititzakete. Kasu hauetan, infekzioak tratatzea oso zaila edo ia ezinezko bilakatzen da. Mekanismo horiek mikroorganismoek garatzen dituzten fenomeno naturalak badira ere, antimikrobianoen erabilera ezegokia dela-eta, bizkortu eta areagotu daitezke. Gauzak horrela, medikamentuekiko erresistenteak diren infekzioak medikuntzarentzat erronka izateaz gain, mundu mailako osasun-mehatxu bilakatu dira [1]. Egun, antimikrobianoekiko erresistentziak (AME) direla-eta, estimatzen da urtean 700.000 hildako baino gehiago daudela. AMEn propagazioa murrizteko neurririk hartu ezean, zifra hori 2050. urtean 10 milioira igo daitekeela uste da [2].

Egoera honetan, 2017. urte hasieran Osasunaren Munduko Erakundeak antibiotiko berrien premia duten bakterio erresistenteen zerrenda argitaratu zuen. Horrela, giza osasunarentzat arriskutsuen jotzen diren 12 patogenofamiliak 3 talde desberdinetan banatu ziren, lehentasun mailaren arabera: kritikoa, altua eta erdi mailakoa [3]. Kritikoen artean ospitale zein pertsona nagusien egoitzetan infekzio larriak eragiteagatik bereziki arriskutsuak diren bakterio multirresistenteak daude: A. baumannii, $P$. aureginosa eta zenbait enterobakterio. Lehentasun altua edo erdi mailakoa dutenen artean, aldiz, botikekiko geroz eta erresistenteago bilakatzen ari direnak daude, $E$. faecium, S. aureus edota $H$. influenzae, esaterako.

Zerrenda honen helburu nagusia antibiotikoen ikerketarako eta garapenerako $(\mathrm{I}+\mathrm{G})$ lehentasunak ezartzea da, eta mundu mailako koordinazioa bermatu. Izan ere, antimikrobiano berrien beharra bistakoa bada ere, ez da farmako hauetan asko inbertitzen. Horrela, 2003. eta 2013. urte-tartean industria farmazeutikoak I+Gra bideratutako kapitalaren $\% 5$ baino gutxiago gastatu zuen antimikrobianoak aztertzen [4]. Horren zergatietako bat da medikamentu hauen salmentek beraien garapenean inbertitutakoa ez dutela konpentsatzen. Ondorioz, azken urteotan nabarmenki murriztu da antimikrobiano berrien garapena.

Botika berrien gabezia horrek egungo antibiotikoen efikazia babesteko premia areagotzen du. Erabilera egokirako, agente infekziosoek farmakoari dioten sentikortasunaz gain, medikamentuen, pazienteen eta mikroorganismoaren artean gertatzen diren elkarrekintza konplexuak ere kontuan hartu behar dira (1. irudia). Bada, hauen arteko aniztasunak dosi-erantzun erlazioan aldakortasun handia eragin dezake. 


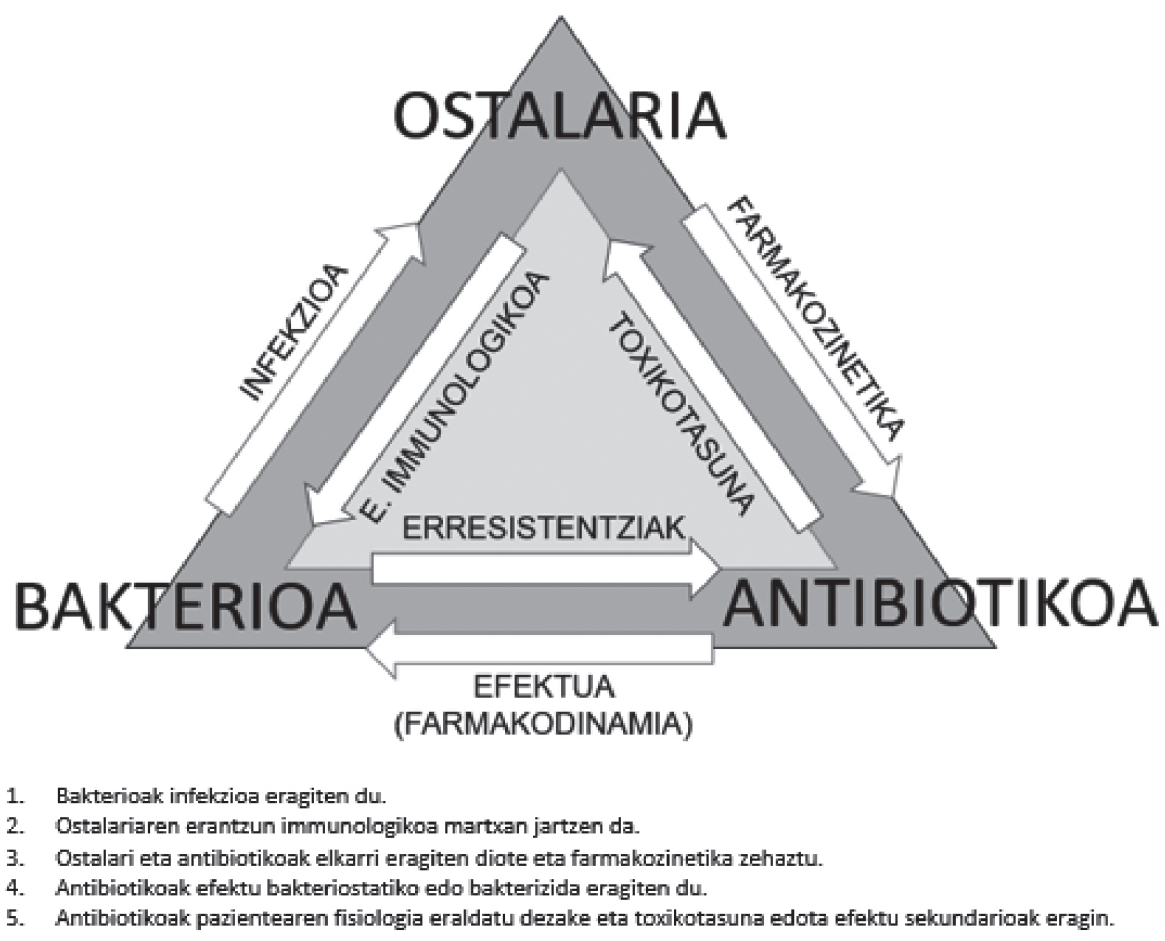

1. irudia. Ostalarien, mikroorganismoen eta antibiotikoaren arteko elkarrekintzak.

Beste botika batzuekin gertatzen ez den bezala (antihipertentsibo edota basopresoreak, esaterako), klinikan ezin daiteke antibiotikoen efektua zuzenean neurtu. Horregatik, zenbait paziente-taldetan bereziki zaila da hautatzea zein den beraien tratamendurako antibiotiko eraginkorrena eta dosifikazio egokiena. Horren adibide dira gaixo pediatrikoak zein kritikoak.

\section{ANTIBIOTERAPIA GAIXO LARRIETAN}

Nahiz eta zerbitzuen zein pazienteen artean aldakortasun handia egon, infekzioek mundu osoko zainketa intentsiboko unitateetan (ZIU) zehar presentzia nabarmena dute. Alde batetik, bertan ospitaleratzearen zergatietako bat infekzioak izan ohi direlako (hala nola, pneumonia, meningitisa edo sepsia). Bestetik, gaitz desberdinengatik ingresaturiko pazienteak osasun-asistentziarekin erlazionatutako infekzioekin kutsa daitezkeelako [5]. «Osasun-asistentziarekin erlazionatutako infekzio» terminoak pazientearen zainketarekin loturiko infekzio guztiak barne hartu arren, jakina da, oroko- 
rrean, ZIUetan tasa altuagoan gertatzen direla, gaixoen ahultasuna eta erabilitako teknika inbasiboak direla eta, besteak beste [6]. Horrela, munduko 75 estatuk esku hartu zuten prebalentzia-ikerketa batean (EPIC II) [7], non 1.265 ZIU desberdinetako parte-hartzaileak egon ziren, eta gaixoen \% 51 infekzioren bat jasaten ari zirela konprobatu zuten. Horien artean nagusi ziren biriketako infekzioak $(\% 63,5)$, infekzio intraabdominalak $(\% 19,6)$ eta bakteriemiak $(\%$ 15,1). Beste pazienteekin konparatuz, kutsatutakoen artean heriotza-tasa altuagoa izan zen, $\% 11$ eta $\%$ 25, hurrenez hurren [7].

Beharbada horren ondorioz, nahiz eta ospitaleratzeen \% 10 baino gutxiago izan, gaixo kritikoek bestelako pazienteek baino hamar bat aldiz antibiotiko-kopuru handiagoa hartzen dute [8].

Kontsumo altu horren beste arrazoietako bat izan daiteke ZIUetako patogenoek antibiotikoei orokorrean baino sentikortasun baxuagoa diotela, medikamentu hauek maizago erabiltzeak erresistentziak sorrarazteko presio selektiboa eragiten baitu $[9,10]$. Patogeno erresistenteen agerpenak antibiotikoen erabilera inplikatzen duen praktika klinikoa etengabe aldatu behar izatea eragiten du. Horren adibide dira, alternatiba gehiago ez edukitzeagatik, azken urteotan toxikotasun-arazoak direla-eta, aspaldi erabiltzeari utzi zitzaion antibiotikoak berriz ere ematen hasi izana (kolistina, adibidez), eta administrazio-formula berriak garatzea [11].

Gaixo kritikoen egoera fisiopatologiko bereziak eta jasaten dituzten interbentzio eta tratamendu farmakologikoak direla eta, zaila da antibiotikoen protokolo estandarrekin posologia egokia ezartzea. Alde batetik, aipatu bezala, orokorrean patogeno erresistenteagoek eragin ohi dituztelako infekzioak. Bestetik, medikamentuen dosi-erregimenen ezarpena boluntario osasuntsuekin burututako entsegu klinikoetan egiten delako, eta ondoren, gaixo ez hain larrietan dosifikazioaren doikuntza egin. Horrela, sarritan paziente kritikoetan farmakoen farmakozinetika eta farmakodinamia aldatuta egoten denez, ez dira askotan espero diren kontzentrazioak lortzen. Ondorioz, maiz gertatzen dira dosi baxuek eragindako porrot terapeutikoa, edo akumulazioak eragindako toxikotasuna [12].

\section{FARMAKOZINETIKA (PK)}

\subsection{Kontzeptua}

Farmakozinetikak farmakoen eta haien metabolitoen kontzentrazioen eboluzioa aztertzen du denboran zehar, pazienteen fluido desberdinetan. Hori dela eta, «gorputzak medikamentuari egiten diona» aztertzen duela esaten da. Behin administratuta, LADME prozesuek (askapena, xurgapena, banaketa, metabolismoa eta iraizketa biltzen dituen ingeleseko terminoa) baldintzatuko dute botika baten kontzentrazio-denboraren profila. Be- 
raz, farmakoen portaera farmakozinetikoa LADME prozesu horien menpe egongo da, eta hainbat parametro farmakozinetiko erabiliz karakteriza daiteke (2. irudia).

\section{Glosarioa:}

$\checkmark$ Banaketa bolumena ( $\mathrm{dd}$, ingeleseko volume of distribution): Organismoan dagoen farmako kantitatearen eta kontzentrazio plasmatikoaren arteko proportzionaltasun konstantea.

$\checkmark$ Argitzapena (CL, ingeleseko clearance): Denbora unitateko eliminazio prozesuak direla eta farmakoz garbitzen den odol bolumenari deritzo. Farmakoaren eliminazio abiadura kontzentrazio plasmatikoarekin erlazionatzen duen konstantea da.

$\checkmark$ Kontzentrazio maximoa $\left(C_{\max }\right)$ : Farmako batek lortzen duen kontzentrazio plasmatiko altuena.

$\checkmark$ Bioerabilgarritasuna: Amerikar farmazeutikoen elkartearen arabera, era farmazeutikotik atera ondoren, zirkulazio sistemikora ailegatzen den farmako edo osagai eraginkor baten kantitatea eta abiadura da.

$\checkmark$ Kurba azpiko azalera (AUC, ingeleseko area under the curve): Organismoak farmako batekiko duen esposizioa neurtzen duen parametroa da. Oso baliagarria da bioerabilgarritasuna kalkulatzeko, besteak beste.

2. irudia. PKn erabiltzen diren zenbait terminoren definizioa.

\subsection{Aldaketa farmakozinetikoak gaixo larrietan}

Antibiotikoei dagokienez, bereziki hiru dira gaixo larrietan aldaketa farmakozinetikoak eragin ditzaketen egoerak: Vd-a handitzea, proteinekiko lotura modifikatzea eta CLan aldaketak gertatzea. Dena den, oso ohikoa da PK baldintzatu dezaketen egoera desberdinak aldi berean gertatzea, eta honek kontzentrazioen iragarpen egokia gauzatzea zailtzen du [13].

\subsubsection{Banaketa-bolumena handitzea}

Edemak sortzean, sepsietan edota erredura handien fase postakutuetan, farmakoen Vd-a handitu ohi da, bereziki likido interstiziala baldintzatuz. Bestalde, ZIUetan sarritan egiten diren bestelako interbentzioek ere (berpizte-fluidoek, bentilazio mekanikoak edota drainatze poskirurgikoek) Vd-a handitu dezakete $[13,14]$. Horrek antibiotikoen kontzentrazioaren murrizketa eragiten du, batez ere molekula hidrofilikoena. Handipen hori nabarmenagoa izango da Vd-a txikia duten antibiotikoetan, betalaktamikoak edota aminoglikosidoak, esaterako [13].

\subsubsection{Proteinekiko lotura modifikatzea}

Proteinekiko lotura farmakoen propietate garrantzitsua da; izan ere, soilik frakzio askeak dauka efektua eragiteko gaitasuna. Gaixo kritikoetan oso 
ohikoa izaten da hipoalbuminemia. Horrela, ZIUetan onarturiko pazienteen $\%$ 40-50ek $25 \mathrm{~g} / \mathrm{L}$ baino albumina-kontzentrazio baxuagoak dituztela ikusi da [15]. Gainera, proteinetara lotzeko antibiotikoen eta beste medikamentu batzuen arteko lehia egon daiteke. Faktore hori proteinekiko lotura handia duten antibiotikoekin hartu beharko da aintzat batik bat, besteak beste, daptomizinarekin (\% 90) eta ertapenemenekin (\% 95-92) [13]. Hasiera batean, proteinen kontzentrazio baxuagoak farmakoaren frakzio askearen proportzioa handitzea ekar dezake, eta horrek efektua eragiteko (alegia, bakterioak hiltzeko) probabilitatea handitzen du. Dena den, proteinekiko lotura handia duten medikamentuetan, hipoalbuminemia Vd-aren handipenarekin eta medikamentuen CL azkarragoarekin erlazionatuta egoten da normalean. Beraz, kasuistika desberdinak gerta daitezke, dosifikazio optimoa aukeratzerakoan aztertu beharko direnak [16].

\subsubsection{Argitzapenean aldaketak}

Farmako gehienak gibel-metabolismoz edo giltzurrun-iraizketaz eliminatzen dira. Gaixo larrietan organo hauen funtzionalitatea eraldatuta egon ohi denez, antimikrobianoen argitzapena baldintzatzen da. Kontuan hartu beharreko egoera nagusiak dira gibel-disfuntzioa, giltzurrun-gutxiegitasun akutua eta giltzurrun-funtzioa handitua izatea.

\section{a) Gibel-disfuntzioa}

Gaixo larrietan gibel-gutxiegitasuna infekzioekin loturiko kolestasiarekin eta min hepatozelularrarekin dago erlazionatuta gehien bat [17], nahiz eta farmako hepatotoxikoak administratzeagatik ere gerta daitekeen, besteak beste $[13,17]$. Egoera honetan medikamentuen metabolismo hepatikoa moteldu daiteke. Hala ere, botika baten argitzapen hepatikoa zehaztea ez da lan erraza izaten, ez baitago gibel-funtzioa espezifikoki neurtzea ahalbidetzen duen markatzailerik. Gutxiegitasun hepatikoa gibel-entzimen igoerarekin dago erlazionatuta, baita bilirrubinarenarekin eta amoniakoarenarekin ere. Bestalde, koagulazio-faktoreen eta albuminaren sintesiaren murrizpena ekar dezake [16] eta horrek, aipatu bezala, farmakoen Vd-an eta proteinekiko loturan eragin dezake.

\section{b) Giltzurrun-gutxiegitasun akutua (GGA)}

Oliguria edo anuria eragiten duen gaitz honek giltzurrun-funtzioaren galtze partziala edo osoa dakar. Ondorioz, kreatinina plasmatikoaren igoera gertatzen da. Proportzio desberdinetan bada ere, antibiotiko-kopuru handia giltzurrun bitartez eliminatzen denez, GGAk eragin nabarmena edukiko du farmako hauen PKn, eta sarritan dosifikazioa egokitzea beharrezkoa izango da. GGAk bizi-arriskua eragiten duenean, giltzurrun-ordezkatze teknikak 
erabiltzen dira, eta horien artean, gehien bat, etengabekoak. Teknika horiek antibiotikoen CLan parte hartzen dute, bereziki proteinekiko lotura txikia dutenetan. Horien bitartez eliminatzen den farmako-kantitatea teknika beraren, filtroaren materialaren eta azaleraren, eta odol fluxuaren menpe egongo da, besteak beste [18].

\section{c) Giltzurrun-funtzio handitua (GFH)}

Nahiz eta gaixo larri askok giltzurrun-gutxiegitasuna pairatu, badaude GFH daukatenak ere. Gaixo hauetan gastu kardiakoa areagotu egiten da, eta, ondorioz, giltzurrunetako odol-fluxua handitzen da eta hiperfiltrazio glomerularra eragiten da. Egun, $130 \mathrm{~mL} / \mathrm{min} / 1,73 \mathrm{~m}^{2}$-ko filtrazio glomerularra duten pazienteak hartzen dira hiperfiltratzailetzat, gehienetan sepsia edota traumatismoren bat duten gizonezko gaixo gazteak izan ohi direnak [19].

Laburbilduz, faktore fisiopatologiko ugarik eragin dezakete antibiotikoen propietate farmakozinetikoetan, eta ZIUetako pazienteen arteko bariabilitate handia antzematen da (aldakortasun interindibiduala). Bestalde, aldaketa hauek indibiduo berean ere gerta daitezke (aldakortasun intraindibiduala), gaixotasunaren larritasuna aldatzen den heinean. Horrela, paziente batentzat momentu batean dosi egokia dena ezegoki bilaka daiteke denbora gutxian.

Gaixo bakoitzari dosifikazio egokia administratzeko, farmakoaren portaera farmakozinetikoari erreparatzea ezinbestekoa bada ere, egunerokotasun klinikoan, ez da medikamentu hauen monitorizazioa egiten. Horrek paziente konkretuetan farmakoaren PK ezezaguna izatea eragiten du. Bestalde, zenbaitetan, paziente-talde berezi batentzat dosifikazio-gomendioak egin nahi izaten dira. Kasu horietan guztietan, informazioa aurretik egindako populazio-ikerketetatik lortu behar da.

Populazio-eredu farmakozinetiko bat garatzeko, efektu mistoetako modelizazio ez-lineala tresna baliagarria da. Horrek modelo estrukturala, bariabilitate interindibiduala eta bakarkako aldakortasuna hartuko ditu barne. Hortaz, populazioaren batez besteko parametro farmakozinetikoak eta gaixoen arteko aldakortasuna kontuan hartuko ditu.

Gainera, populazio-eredu farmakozinetikoek aldagai desberdinak ere aintzat izango dituzte, eta modu horretan, pazienteen ezaugarri desberdinek PKn duten eragina zehaztuko dute. Adibidez, kreatinina argitzapena (CLcr) erabiliaz, pazienteen giltzurrun-funtzioak antibiotikoen CLan duen eragina kuantifika daiteke (3. irudia).

Populazio-eredu farmakozinetikoetan aldagaiak gehitzean, neurri batean, pazienteen arteko aldakortasuna azaltzen da, farmako-dosifikazio egokia ezartzen laguntzen duena. 


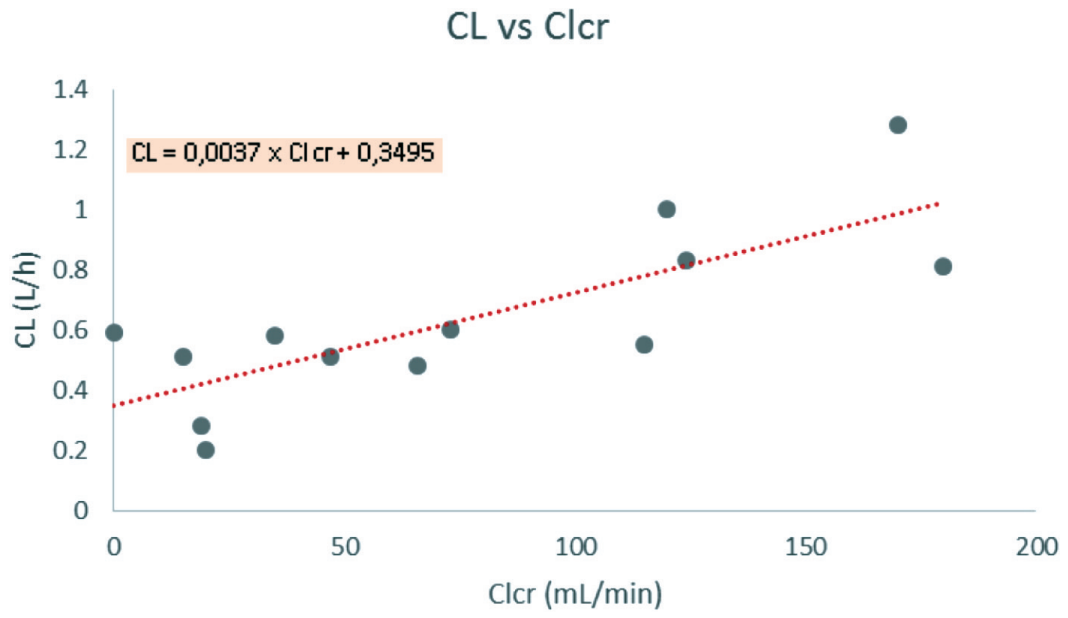

3. irudia. Farmako baten CLaren eta Clcr-aren arteko erlazioa.

\section{FARMAKODINAMIA (PD)}

\subsection{Kontzeptua}

Medikamentuen posologia optimizatzeko, $\mathrm{PKz}$ gain, farmakodinamia ere kontuan hartu behar da. Farmakodinamiak medikamentu batek, bere ekintza mekanismoari esker, kontzentrazio zehatz batean, organismoan eragiten dituen efektu biokimiko eta fisiologikoak aztertzen ditu. Sinplifikatuz, «farmakoak gorputzari egiten diona» bezala definitu izan da. Terapia antimikrobianoan, farmakoaren esposizioa eta efektu mikrobiologiko edo klinikoa erlazionatzen duen jakintzagaia da [20, 21].

Antibiotiko baten efektua neurtzeko erabiltzen den adierazle nagusia MICa da. Adierazle hau kalkulatzeko metodologia desberdinak erabiltzen dira, E-testa, Bauer-Kirby metodoa edota mikrodiluzioa, esaterako [22]. Hortaz, MICak modu estatikoan, mikroorganismoen eta antibiotikoen arteko elkarrekintza baino ez du kontuan hartzen, ostalariarekin dituztenak aintzat hartu gabe (4. irudia).

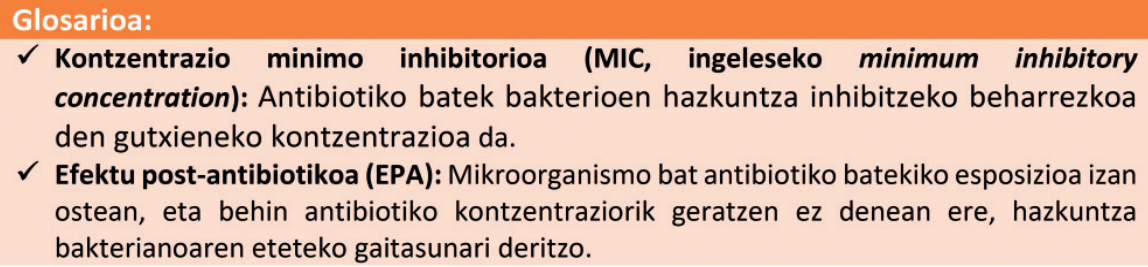

4. irudia. Antibiotikoen eragina ebaluatzeko erabiltzen den zenbait terminoren definizioa. 
PDa medikamentuaren kontzentrazioaren menpe dagoenez, eta kontzentrazioa farmakoaren PK-k baldintzatzen duela kontuan hartuz, PK eta PDa estuki erlazionatuta daude (5. irudia). Analisi farmakozinetiko/farmakodinamikoak indibiduo desberdinentzat eta infekzio mota bakoitzarentzat antibiotikoen dosi egokiena aukeratzea ahalbidetzen du, eta efektu desiragaitzak edota erresistentziak agertzea saihesten du.

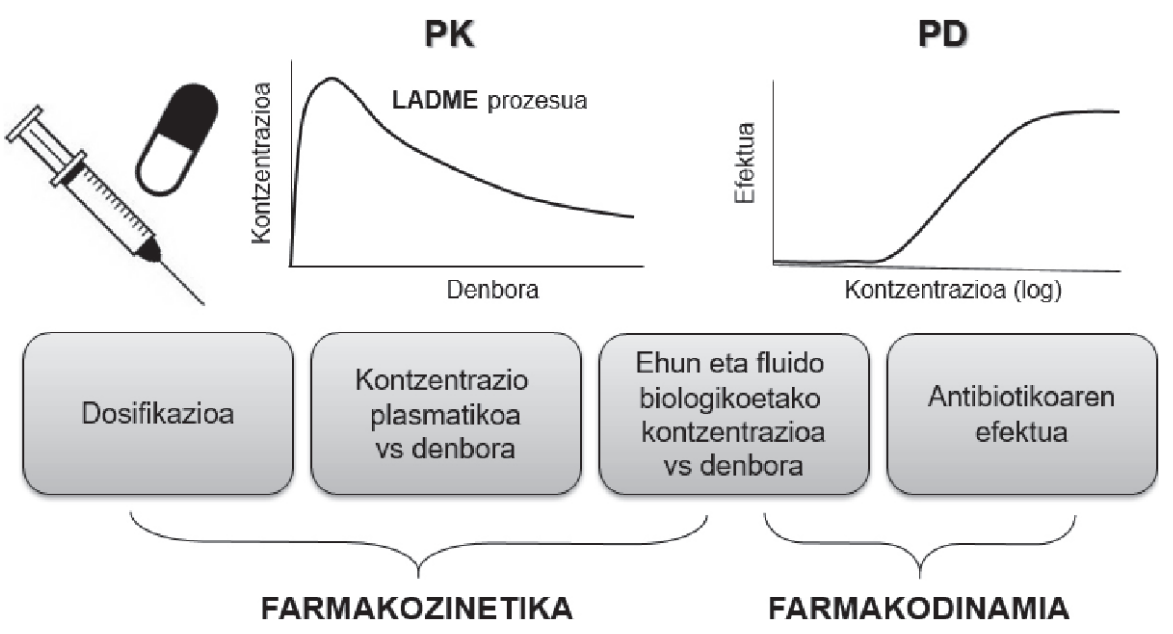

5. irudia. PKren eta PDren arteko erlazioa.

\subsection{Indize farmakozinetiko/farmakodinamikoak}

Parametro farmakozinetikoen eta mikrobiologikoen arteko erlazio kuantitatiboari indize farmakozinetiko/farmakodinamiko (I-PK/PD) deritzo. Antibiotikoen efektua aurreikusteko hiru deskribatu dira (6. irudia). Alde batetik, kontzentrazio plasmatikoak MIC balioaren gainetik mantentzen diren denbora $\left(\mathrm{T}_{>\text {MIC }}\right)$; bestetik, antibiotikoaren kontzentrazio maximoaren eta MICaren arteko ratioa $\left(\mathrm{C}_{\max } / \mathrm{MIC}\right)$, eta azkenik, farmakoaren kontzentrazioen 24 orduko kurba azpiko azaleraren (AUC) eta MICaren arteko erlazioa (AUC/MIC) [23, 24]. Indize horiek balio jakin bat lortu beharko dute eraginkortasuna bermatzeko.

Antibiotikoek daukaten aktibitate-patroiaren arabera, terapiaren efikazia ebaluatzeko I-PK/PD bat edo beste erabiltzea gomendatzen da. Horren arabera hiru dira desberdintzen diren taldeak. Lehenengo multzokoek kontzentrazioaren menpeko eragina daukate, EPA luzearekin. Kasu honetan, medikamentu-kontzentrazio altuek efektu azkarragoa eta heriotza bakterianoa eragiten dute. Beraz, efikaziarekin hobekien korrelazionatzen diren I-PK/PDak $\mathrm{C}_{\max } / \mathrm{MIC}$ eta AUC/MIC izango dira. Patroi hau jarraitzen duten antibiotikoen dosifikazioa optimizatzeko dosi altuak eta denbora-tarte 


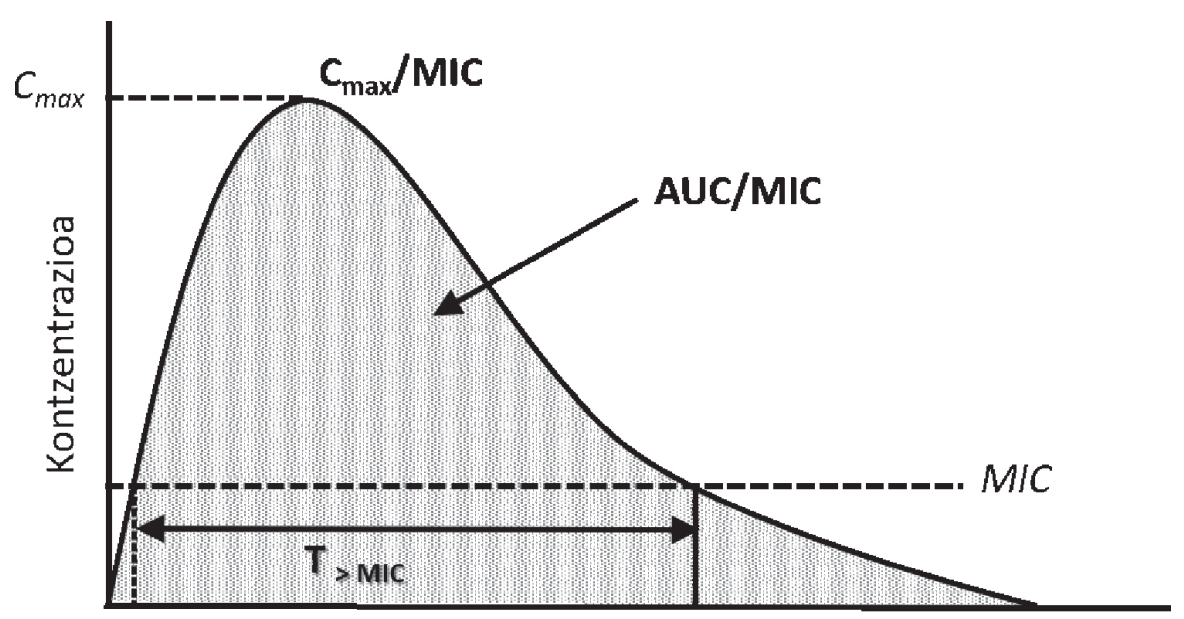

Denbora

6. irudia. Antibiotikoen efikaziarekin erlazionatuta dauden I-PK/PD.

luzeak erabiltzen dira. Talde honen barruan daude aminoglikosidoak eta fluorokinolonak, besteak beste [23, 24].

Bigarren taldea EPA motzeko eta denboraren menpeko efektua daukaten antibiotikoek osatzen dute. Beraien efikazia zehazteko $\mathrm{T}_{>\mathrm{MIC}}$ indizea erabiltzen da. Horrela, medikamentu baten erdibizitza geroz eta motzagoa izan, orduan eta maiztasun handiagoan administratu beharko da. Zenbait kasutan, bereziki behar den $\mathrm{T}_{>\text {MIC }}$ altua denean, benabarneko perfusioa beharrezkoa izan daiteke. Talde honen barruan antibiotiko betalaktamikoak daude $[23,24]$.

Azkenik, antimikrobiano batzuk kontzentrazioarekiko independente den efektua dute, EPA luzearekin. Antibiotiko-kontzentrazio altuek heriotza bakterianoa handitzen dute arinki, baina mikroorganismoen hazkuntza inhibituko dute luzaroko. Talde honetan erabiltzen diren indikadoreak AUC/MICa edo $\mathrm{C}_{\max } / \mathrm{MICa}$ dira eta linezolid edo bankomizina bezalako antibiotikoak hartzen ditu barne [23, 24].

Esan bezala, analisi farmakozinetiko/farmakodinamikoa egokia egiteko, I-PK/PD aproposa aukeratzeaz gain, antibiotiko bakoitzarekin arrakasta terapeutikoa lortzeko behar den indizearen balio zehatza ere determinatu behar da, alegia, helburu farmakodinamikoa determinatu behar da (PDT) [25]. Antibiotiko baten dosifikazio bat eraginkortzat hartzeko, beraz, dagokion I-PK/PDarentzat PDT jakin batera heltzen den aztertu beharko da, zeina aurretik egindako in vivo zein in vitro ikerketetan zehaztu den. 
Adibide moduan, 1. taulan zenbait antibiotikoren I-PK/PDak zein PDTak jaso dira $[20,26,27,28,29,30]$.

1. taula. Zenbait antibiotikoren aktibitate mota, I-PK/PDak eta PDTak.

\begin{tabular}{|c|c|c|c|}
\hline Aktibitate mota & Antibiotikoa & $\begin{array}{c}\text { Indize } \\
\text { farmakozinetiko/ } \\
\text { farmakodinamikoa }\end{array}$ & $\begin{array}{c}\text { Helburu } \\
\text { farmakodinamikoa }\end{array}$ \\
\hline \multirow{2}{*}{$\begin{array}{l}\text { Kontzentrazioaren-menpekoa } \\
\text { EPA luzearekin }\end{array}$} & Aminoglikosidoak & $\mathrm{C}_{\max } / \mathrm{MIC}$ & $10^{26}$ \\
\hline & $\begin{array}{l}\text { Fluorokinolonak } \\
\text { Daptomizina }\end{array}$ & AUC/MIC & $\begin{array}{l}125^{27} \\
666^{28}\end{array}$ \\
\hline \multirow{3}{*}{$\begin{array}{l}\text { Denboraren- menpekoa } \\
\text { EPA motzarekin }\end{array}$} & Betalaktamikoak: & \multirow{3}{*}{$T_{\text {SMIC }}$} & $50-60^{20}$ \\
\hline & Penizilinak & & $60-70^{20}$ \\
\hline & $\begin{array}{l}\text { Zefalosporinak } \\
\text { Karbapenemak }\end{array}$ & & $40-50^{20}$ \\
\hline Kontzentraziorekiko & Linezolid & AUC/MIC -- T $>$ MIC & $100--85^{29^{*}}$ \\
\hline $\begin{array}{l}\text { independentea } \\
\text { EPA luzearekin }\end{array}$ & Bankomizina & $\mathrm{AUC} / \mathrm{MIC}$ & $400^{30}$ \\
\hline
\end{tabular}

"Linezoliden kasuan, AUC/MIC edota TsMic indizeak aintzat hartu izan dira

\section{ANALISI FARMAKOZINETIKO/FARMAKODINAMIKOA ETA MONTE CARLO SIMULAZIOA}

Gaixo larrietan pertsonen arteko aldakortasuna nabaria izan ohi da eta ZIUetan egindako ikerketan parte hartzen duen gaixo-kopurua mugatua izaten da. Informazio murritz honek dosifikazioen doikuntza ezegokia edota, helburu terapeutikoak lortzeari dagokionez, predikzio okerrak egitera eraman gaitzake. Hori gerta ez dadin, indibiduoen arteko aldakortasuna aintzat hartu eta laginaren tamaina handiagotu edo maximizatu egiten duten estrategiak egin daitezke, Monte Carlo simulazioa (MCS) erabiliz [31]. MSCk, aurretik eraikitako eredu farmakozinetikoaren ekuazioak aintzat hartzen ditu eta, indibiduo desberdinen artean lortutako parametroen distribuzioa kontuan hartuz (batezbestekoa eta desbiderapen estandarra, esaterako), milaka subjektu desberdin simulatzen ditu.

Simulazio horiek, beraz, baliagarriak izango dira terapia enpirikoan zein populazio berezietan (gaixo larriak, paziente obeso zein zaharrak, etab.) dosifikazio optimoak aurreikusteko. Dena den, emaitza fidagarriak lortzeko eta alborapenik egon ez dadin, nahitaezkoa izango da balioztatu den eredu farmakozinetiko bat edukitzea, barne hartzen dituen aldagaiak kontuan hartuz. Bestalde, ezinbestekoa izango da ere PKren eta PDaren arteko erlazioa ondo definitzen duen eredu farmakodinamikoa izatea. 
MCSa egitean, helburu farmakozinetiko/farmakodinamikoa lortzeko probabilitateen (PTA) kalkulua egiten da. PTAk MIC balio zehatz batentzat, I-PK/PDak balio jakin bat lortzeko probabilitatea zehazten du. Hau da, simulatutako pazienteen zein ehunekok lortzen duen I-PK/PDaren balio berdina edo handiagoa determinatzen du, MIC balio konkretu batentzat.

Hala ere, askotan, eguneroko praktika klinikoan ez da mikroorganismoen sentikortasuna ezagutzen. Kasu horietan, baliagarria izan daiteke erantzunaren metatze-frakzioa (CFR) erabiltzea. CFRak antibiotiko baten dosifikazio-erregimen zehatz batek arrakasta izateko probabilitatea kalkulatzen du, MICen balio espezifikorik egon ez, baina populazio batean hauen frekuentzia ezaguna denean. Parametro hau MIC balio jakin batentzat PDTa lortzeko probabilitatea eta MIC balio hori duten anduien ehunekoa biderkatzen lortzen da, eta azkenik, MIC desberdinentzat lortutako emaitzak gehitzen dira (7. irudia).

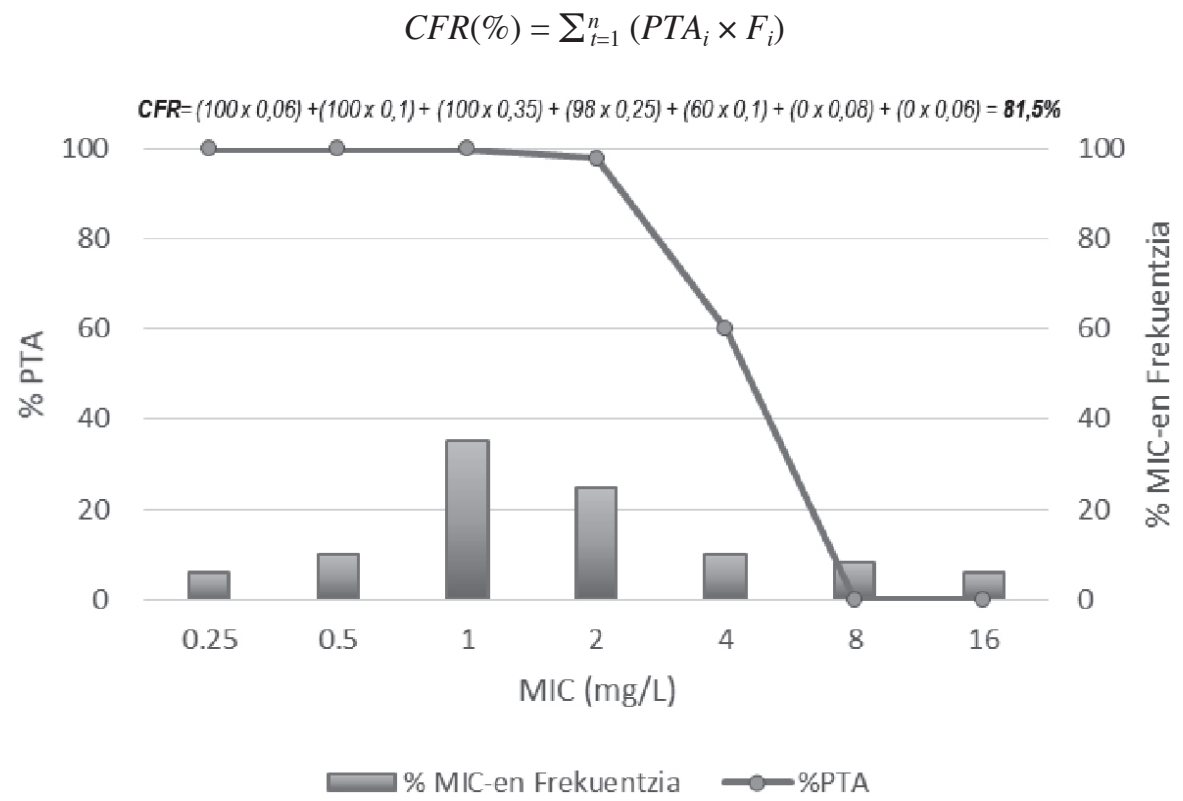

7. irudia. Antibiotiko jakin baten CFRaren kalkulua; MICen distribuzioa ( $\% F)$ eta MIC hauetako bakoitzarentzat helburuak lortzeko probabilitatea (\% PTA) kontuan harturik.

Hurbilketa hau patogenoen sentikortasuna oraindik ezaguna ez denetan baliagarria izan daiteke; baita ospitale konkretu batean antibiotiko baten dosifikazio-erregimen egokiena zein den determinatzeko ere. Hala ere, CFRaren estimazio egokia egiteko, ezinbestekoa izango da aurretik MICen 
distribuzioa leku eta denbora konkretu batentzat ondo zehaztua izatea. Izan ere, bakterioek antibiotikoekiko duten sentikortasun-patroiak alda daitezke denboran zehar, baita lurralde, ospitale zein zerbitzu artean ere. Hori dela eta, askotan literaturan argitaratutako MICen balioak ez dira momentu zehatz bateko errealitatearen adierazgarri.

\section{ONDORIOAK}

Analisi farmakozinetiko/farmakodinamikoak, populazioaren modelizazio farmakozinetikoarekin eta MCSekin batera, antibiotikoen dosifikazio-erregimenen optimizazioa egitea ahalbidetzen du. Hau bereziki erabilgarria izango da gaixo kritikoetan. Alde batetik, farmakoen PK modu nabarian eraldatuta izan ohi dutelako, eta bestetik, infekzioak antibiotikoekiko erresistenteagoak diren mikroorganismoek eragiten dizkietelako.

\section{BIBLIOGRAFIA}

[1] ROCA I, AKOVA M, BAQUERO F et al. 2015. «The global threat of antimicrobial resistance: science for intervention». New Microbes New Infect, $\mathbf{6}$, 22-29.

[2] https://amr-review.org/Publications.html (2016/05).

[3] http://www.who.int/medicines/publications/global-priority-list-antibiotic-resistant-bacteria/en/ (2017/02).

[4] SILVER LL. 2011. «Challenges of antibacterial discovery». Clin Microbiol Rev. 24(1), 71-109.

[5] BURKE A. CUNHA. 2010. Infectious Diseases in Critical Care Medicine (Third Edition). Informa Healthcare USA, Inc. 52 Vanderbilt Avenue New York, NY 10017.

[6] ALBERTI C, BRUN-BUISSON C, BURCHARDI H, et al. 2002. «Epidemiology of sepsis and infection in ICU patients from an international multicentre cohort study». Intensive Care Med. 28, 108-21.

[7] VINCENT JL, RELLO J, MARSHALL J, et al.; EPIC II Group of Investigators. 2009. «International study of the prevalence and outcomes of infection in intensive care units». JAMA. 302(21), 2323-9.

[8] ABDUL-AZIZ MH, LIPMAN J, HOPE WW, et al. 2015. «Applying pharmacokinetic/ pharmacodynamic principles in critically ill patients: optimizing efficacy and reducing resistance development». Semin Respir Crit Care Med.36(1), 136-53.

[9] SAVAGE RD, FOWLER RA, RISHU AH, et al. 2016. «Pathogens and antimicrobial susceptibility profiles in critically ill patients with bloodstream infections: a descriptive study». CMAJ Open.4(4), E569-E577. 
[10] RHOMBERG PR, FRITSCHE TR, SADER HS, JONES RN. 2006. «Antimicrobial susceptibility pattern comparisons among intensive care unit and general ward Gram-negative isolates from the Meropenem Yearly Susceptibility Test Information Collection Program (USA)». Diagn Microbiol Infect Dis. 56(1), 57-62.

[11] CASSIR N, ROLAIN JM, BROUQUI P. 2014. «A new strategy to fight antimicrobial resistance: the revival of old antibiotics». Front Microbiol. 5, 551.

[12] DEL MAR FERNÁNDEZ DE GATTA M, MARTÍN- SUÁREZ A, LANAO JM. 2013. «Approaches for dosage individualisation in critically ill patients». Drug Metab Toxicol.9(11), 1481-93.

[13] BLOT SI, PEA F, LIPMAN J. 2014. «The effect of pathophysiology on pharmacokinetics in the critically ill patient - Concepts appraised by the example of antimicrobial agents». Adv Drug Deliv Rev. 77, 3-11.

[14] ÁLVAREZ-LERMA F, GRAU S. 2012. «Management of antimicrobial use in the intensive care unit». Drugs. 72(4), 447-70.

[15] ULLDEMOLINS M, ROBERTS JA, RELLO J, PATERSON DL, et al. 2011. «The effects of hypoalbuminaemia on optimizing antibacterial dosing in critically ill patients». Clin Pharmacokinet. 50(2), 99-110.

[16] ROBERTS JA, JOYNT GM, CHOI GY, GOMERSALL CD, et al. 2012. «How to optimise antimicrobial prescriptions in the Intensive Care Unit: principles of individualised dosing using pharmacokinetics and pharmacodynamics». Int J Antimicrob Agents. 39(3), 187-92.

[17] CHAND N, SANYAL AJ. 2007. «Sepsis-induced cholestasis». Hepatology. 45(1), 230-41.

[18] THONGPRAYOON C, CHEUNGPASITPORN W, AHMED AH. 2015. «Trends in the use of renal replacement therapy modality in intensive care unit: a 7 year study». Ren Fail. 37, 1444-7.

[19] HOBBS AL, SHEA KM, ROBERTS KM, DALEY MJ. 2015. «Implications of Augmented Renal Clearance on Drug Dosing in Critically Ill Patients: A Focus on Antibiotics». Pharmacotherapy. 35(11), 1063-75.

[20] DRUSANO GL. 2004. «Antimicrobial pharmacodynamics: critical interactions of «bug and drug»». Nat Rev Microbiol. 2, 283-300.

[21] SCHMIDT S, SCHUCK E, KUMAR V, et al. 2007. «Integration of pharmacokinetic/ pharmacodynamic modeling and simulation in the development of new anti-infective agents-minimum inhibitory concentration versus time-kill curves». Expert Opin Drug Discov.2(6), 849-60.

[22] ANDREWS, JM. 2001. «Determination of minimum inhibitory concentrations». J Antimicrob Chemother. 48 Suppl 1:5-16.

[23] SCAGLIONE F. 2010. «Pharmacokinetic/Pharmacodynamic (PK/PD) considerations in the management of Gram-positive bacteraemia». Int $J$ Antimicrob Agents. 36 Suppl 2, S33-9. 
[24] LODISE TP, DRUSANO GL. 2011. «Pharmacokinetics and pharmacodynamics: optimal antimicrobial therapy in the Intensive care unit». Crit Care Clin. 27(1), 1-18.

[25] ASÍN-PRIETO E, RODRÍGUEZ-GASCÓN A, ISLA A. 2015. «Applications of the pharmacokinetic/pharmacodynamic (PK/PD) analysis of antimicrobial agents « $J$ Infect Chemother. 21(5), 319-29.

[26] KASHUBA AD, NAFZIGER AN, DRUSANO GL, et al. 1999. «Optimizing aminoglycoside therapy for nosocomial pneumonia caused by gram-negative bacteria». Antimicrob Agents Chemother 43, 623-629.

[27] SCHENTAG JJ. 1999. «Pharmacokinetic and pharmacodynamic surrogate markers: studies with fluoroquinolones in patients». Am J Health Syst Pharm. 56(22 Suppl 3), S21-4.

[28] CANUT A, ISLA A, BETRIU C, et al. 2012. «Pharmacokinetic-pharmacodynamic evaluation of daptomycin, tigecycline, and linezolid versus vancomycin for the treatment of MRSA infections in four western European countries». Eur J Clin Microbiol Infect Dis. 31(9), 2227-35.

[29] PEA F, VIALE P, COJUTTI P, et al. 2012. «Therapeutic drug monitoring may improve safety outcomes of long-term treatment with linezolid in adult patients». J Antimicrob Chemother. 67, 2034-42.

[30] MOISE-BRODER PA, FORREST A, BIRMINGHAM MC, et al. 2004. «Pharmacodynamics of vancomycin and other antimicrobials in patients with Staphylococcus aureus lower respiratory tract infections.»Clin Pharmacokinet. 43(13), 925-42.

[31] ROBERTS JA, KIRKPATRICK CM, LIPMAN J. 2011. «Monte Carlo simulations: maximizing antibiotic pharmacokinetic data to optimize clinical practice for critically ill patients». J Antimicrob Chemother. 66(2), 227-31. 